\title{
Value Added Tax as an important factor of tax revenues in the Republic of Kosovo
}

\author{
Gentiana Mjaku, Ph.D. c. ${ }^{* *}$ \\ Department of Marketing, Faculty of Economics, University of Tetova \\ DOI: 10.29322/IJSRP.10.08.2020.p104114 \\ http://dx.doi.org/10.29322/IJSRP.10.08.2020.p104114
}

\begin{abstract}
The government uses different instruments to stimulate economic growth, reduce unemployment, and boost up investment, for which purpose, this system since its very beginning has gone through a number of filters of changes and improvements. Any change at the level of these instruments has a direct impact on the overall economic flow. The main purpose of this research is to analyze the role and importance of Value Added Tax (VAT) and its impact on budget revenues. It will assess the relationship between VAT and the generation of tax revenues in Kosovo, the creation of new fiscal reforms, especially related to the Value Added Tax.

In more than 120 countries, VAT is the main source of the government's revenues, which have an impact on around four billion people. This research was conducted by using secondary data which are a result of a review of the tax legislation of the Republic of Kosovo, the Ministry of Finance and various reports published over the years by the Tax Administration of Kosovo for the years 2009 - 2016. These data served to build up the hypotheses and to come up with the results. Econometric Model was also used - Precisely, in this paper work we have analyzed how VAT is the dominant factor in the tax revenues.
\end{abstract}

Index Terms- Value Added Tax, VAT escalation, Republic of Kosovo, tax incomes.

\section{INTRODUCTION}

$\mathrm{K}$ osovo as a new country has managed to establish a sustainable tax system. By establishing the tax system Kosovo aimed at having a harmonized one with the tax system and legal framework of the European Union. Therefore, this system, from its early stage, has gone through a number of different filters of changes and improvements. The main functioning of the tax system logically is to generate revenues for the budget (especially VAT). In more than 120 countries, VAT is the main source of the income for the Government, which has an impact in the lives of around four billion people. This paperwork will explain the purpose, objectives, the hypothesis of the research, literature review and the methodology. In the final part, the analysis and interpretation regarding the VAT as an important factor of the tax incomes will be presented.

${ }^{1}$ Value Added Tax

2 Tax on Wages

\section{a) The subject of the research}

This study aims to determine the VAT role as well as its impact in the generation of domestic revenues. The study will address this objective: It will examine the relationship between VAT and generation of the tax revenues in Kosovo.

Based on the study objectives and the information from the reviewed literature, the following hypothesis has been raised:

H0: VAT doesn't have an important relationship to the generation of incomes.

H1: VAT does have an important relationship to the generation of incomes.

\section{b) Research methodology}

The study is based on the researches of the most famous authors of this area. Literature review was mainly focused in materials, books, articles, reports of institutions, publications dealing with issues related to VAT. Globally, there were some researches with this objective, ie Michael \& Ben (2007) which explores the reasons and consequences of VAT expansion. VAT operation should be simple, transparent and easy in terms of functioning. Deshmukh S.M (2012) examined in his study the VAT's economic impact in the incomes' increase and effectiveness in Maharashtra.

The methodology and the methods applied will be:

Deduction method - In this case, the functioning of the value added tax system, which is applied in most of the states worldwide, in general, has been studied and analyzed, and as a special focus has been the analysis and functioning of VAT in Kosovo and its impact on tax revenues.

Descriptive method -Different materials and reports that have been dealing with the study of taxes in general, and in particular with the value added tax in Kosovo have been collected here. In this case, literature from different authors has been used and reports (secondary data were provided by the Ministry of Finance, Tax Administration of Kosovo and other sources.)

Econometric model was also used - Precisely, in this paperwork we have analyzed how VAT influences tax revenues. For data analysis, the STATA program is used. Taxes are defined as endogenous variables, while exogenous variables are defined as $\mathrm{VAT}^{1}, \mathrm{TW}^{2}$ and $\mathrm{CIT}^{3}$. To study the impact of the Value Added

\footnotetext{
${ }^{3}$ Corporate Income Tax
} 
Tax on generation of revenue, data is collected for the period 2009-2016.

\section{c) Types of taxes in Kosovo}

A usual classification of the taxes is as follows:

$\checkmark$ Direct taxes (CIT) \& (TW) and

$\checkmark$ Indirect taxes (VAT).

\section{VALUE ADDED TAX}

The American interest for VAT can be traced back to 1920s. In one way or another Americans have been talking about VAT for nearly a century. However, there are authors who associate the idea of VAT application with the name of Yale University Professor, Thomas Adams. Adams, a chief economist for taxation of his generation, suggested VAT as a replacement for existing business taxes in the US in 1921. Adams supported a broad-based tax on gross business income. In 1948, VAT was present in France but limited to several activities only. VAT is the main form in the European Union member states. As of 1989, 48 countries, mainly from the Western Europe and Latin America, but also including a small part of the developing countries, had VAT approved. However, due to its inclusive character, other countries such as Japan, China, Canada, Korea, countries in Latin America, Asia, Africa and almost all Eastern European countries had this tax also in place. VAT is not a universal term, but derives from the translation of the original term into French (taxe sur la valeur ajoutee), and can be argued as an added tax value, but is not used in this form. Some countries use the term "tax on goods and services". VAT term is more preferred compared to other terms such as the Goods and Services Tax (GST) as it reflects more precisely the unique nature of this tax.

Kosovo has begun to implement VAT on 1 July 2001 by collecting it at a rate of $15 \%$ above the taxable value. This rate was applied until the end of 2008. As of 1 January 2009 the tax rate was increased from $15 \%$ to $16 \%$. As of September 2015, VAT has escalated to two rates, the standard of eighteen percent $(18 \%)$ and the reduced rate of $8 \%$ of the value of imported supplies and domestic taxable supplies, with the exception of exempt supplies and supplies treated as exports.

VAT is a tax collected through self-declaration of taxable persons. When billing, VAT rate applied to customers, is collected by the taxable person and allocated to the Kosovo Budget. It's applied to all supplies made to customers, which means that for all taxable supplies, VAT shall be charged.

\section{THE ANALYSE OF THE RESULTS}

ECONOMETRIC MODEL - Testing of the hypothesis of the paperwork is done by using the Regression Analysis. The regression equation used can be expressed as follows: $\mathrm{Y}=\mathrm{a}+\mathrm{b} \_1$ $\mathrm{X} 1 \ldots \ldots \ldots$

When: $\mathbf{Y}=$ The total of collected revenues, $\quad \mathbf{a}=$ constant,$\quad \mathbf{B} 1$ $=$ Partial regression coefficient added to variable X1

$\mathbf{X 1}=$ VAT (Value Added Tax $)$

$\mathbf{X} \mathbf{2}=\mathrm{TW}($ Tax on Wages $)$

Table 1: The table of incomes based on main types of taxes in Kosovo 2009-2016

\begin{tabular}{|lllll|}
\hline Years & Incomes & VAT & TW & CIT \\
\hline $\mathbf{2 0 0 9}$ & $206,681,573$ & $75,825,276$ & $39,227,003$ & $55,355,226$ \\
\hline $\mathbf{2 0 1 0}$ & $221,585,852$ & $95,056,532$ & $44,208,929$ & $51,945,804$ \\
\hline $\mathbf{2 0 1 1}$ & $261,123,163$ & $121,437,993$ & $55,668,304$ & $54,564,163$ \\
\hline $\mathbf{2 0 1 2}$ & $283,898,932$ & $129,960,077$ & $60,089,290$ & $62,680,757$ \\
\hline $\mathbf{2 0 1 3}$ & $305,451,932$ & $149,184,989$ & $61,962,028$ & $64,110,827$ \\
\hline $\mathbf{2 0 1 4}$ & $303,694,991$ & $136,939,023$ & $67,857,126$ & $55,318,972$ \\
\hline $\mathbf{2 0 1 5}$ & $332,281,049$ & $155,153,654$ & $72,081,313$ & $61,433,216$ \\
\hline $\mathbf{2 0 1 6}$ & $386,385,285$ & $180,363,400$ & $80,327,270$ & $81,278,873$ \\
\hline Total incomes: & $\mathbf{2 , 3 0 1 , 1 0 2 , 7 7 7}$ & $\mathbf{1 , 0 4 3 , 9 2 0 , 9 4 4}$ & $\mathbf{4 8 1 , 4 2 1 , 2 6 3}$ & $\mathbf{4 8 6 , 6 8 7 , 8 3 8}$ \\
\hline
\end{tabular}

Source: Processing data from the annual reports published by Tax Administration of Kosovo Revenues for the period 2009-2016.

The incomes based on main tax categories, the largest share from 2009 to 2016 has the value added tax (VAT), then corporate income tax and personal income tax. The clarification of the problem is done by means of a descriptive statistic of the variables involved during the formulation of the problem, which was mentioned in the previous parts of the research methodology.

For analysing the data, the statistical software STATA 14.0 has been used. 
Table 2: The results of the analysis for significance and correlation

\begin{tabular}{|l|l|}
\hline Number of obs $=$ & $\mathbf{8 8}$ \\
\hline Prob $>$ F $=$ & 0.000 \\
\hline R - squared $=$ & 0.9956 \\
\hline Source: Calculation of authors in the software STATA \\
\hline
\end{tabular}

Table 3: The results of the regression linear analysis

\begin{tabular}{ll}
\hline & P> t \\
\hline Value Added Tax (VAT) & 0.0000 \\
Tax on Wages (TW) & 0.001 \\
Corporate Income Tax (CIT) & 0.003 \\
\hline
\end{tabular}

Source: Calculation of authors in the software STATA

Based on the above data we have established an econometric model in which the value " $Y$ " is the dependent variable of the model or the tax revenue, while the value " $\mathrm{X}$ " represents the independent variables affecting the dependent variables.

The testing of the significant linkage which can be done by accepting or rejecting hypotheses (The zero hypothesis is accepted if the effect is not the expected one, and vice versa, if the Hypothesis 1 is accepted then the regression is in line with the theoretical predictions) shows that in the cases of incomes and VAT the alternative hypothesis or $\mathrm{H} 1$ which indicates that the results are in line with the theoretical forecast for the positive link between incomes and VAT should be supported or accepted. The probability value at the level of significance $95 \%$ is 0,000 for VAT and 0.00 for TW while 0.003 for CIT, ie less than 0.05 .

\section{CONCLUSIONS}

The VAT as an important factor in revenue generation was analysed in this study, as well as the impact of changing VAT's law. This has become possible by halving the VAT rate at $8 \%$ for basic products and increasing the VAT rate at $18 \%$ for luxury products. VAT increase has had a positive impact on TAK revenues.

The VAT threshold decreases from 50,000 euro to 30,000 euro. Thus, any business that generates an annual turnover of more than 30,000 euro will be obliged to register VAT and to pay for the part that exceeds this amount. Kosovo's budget will benefit from this VAT lowering of the threshold because more businesses will be forced to pay VAT.

Based on the data collected through throughout different reports, if we take into consideration the main types of taxes then we can realize that there was a slight increase each year. If we look at the total tax revenues, as well as the data received from the relevant institutions, and referring to the analysis of STATA program, we can realize there is a positive trend in the tax revenues from these taxes and especially from the Value Added Tax.

\section{REFERENCES}

[1] Alm, J., \& El-Ganainy, A. (2012). Value-added Taxation and Consumption. Tulane Economics Working Paper Series , pp. 20 -27

[2] Khan, M. A., \& Shadab, N. (2013). Impact of Value-Added Tax (VAT) revenue in major states of India. Romanian Journal of Fiscal Policy, Vol. 4 Iss.1(6), pp.27-46.

[3] Njogu, L. K. (2015). The effect of value added tax on economic growth in Kenya. International Academic Journal of Economics and Finance, Vol. 1, Iss. 5, pp. 10-30.

[4] Onwuchekwa, J. C., \& Aruwa, S. A. (2014). Value added tax and economic growth in NIGERIA. European Journal of Accounting Auditing and Finance Research, Vol.2,No.8, pp.62-69.

[5] Williams, D. (1996). Value-Added Tax . International Monetary Fund Volume 1, Chapter 6.

[6] Retrieved from http://www.atk-ks.org (2.01.2018)

[7] Tax Administration of Kosovo. The fulfilment strategy 2012-2015 September, 2011 Pristina. Retrived from http://www.atk-ks.org/wpcontent/uploads/2011/11/Strategjia_e_Permbushjes_2012-2015.pdf on 07.02.2018, https://dogana.rks-gov.net/wpcontent/uploads/2016/11/Raporti.Vjetor.2015.e.SH.76209.pdf (25.01.2018)

[8] http://mf.rks-gov.net/desk/inc/media/432E261B-F151-418C-9E96F35490C69510.pdf (17.03.2018)

[9] http://www.atk-ks.org/wp-content/uploads/2016/05/Sllajdet-Trajtimi-iOJQ-ve-p\%C3\%ABr-TVSh.pdf (17.03.2018)

[10] Annual work report 2010. Retrieved from http://www.atk-ks.org/wpcontent/uploads/2010/09/Raporti-Vjetor-2010_web.pdf (01.03.2018)

[11] Annual work report 2011. Retrieved from http://www.atk-ks.org/wpcontent/uploads/2012/04/Raporti-i-punes-2011.pdf (01.03.2018)

[12] Annual work report 2012. Retrieved from http://www.atk-ks.org/wpcontent/uploads/2013/02/Raporti-Janar-Dhjetor-2012-07-02-2013-PDF.pdf (01.03.2018)

[13] Annual work report 2013. Retrieved from http://www.atk-ks.org/wpcontent/uploads/2010/09/Raporti-i-punes-per-vitin-2013.pdf (01.03.2018)

[14] Annual work report 2014. Retrieved from http://www.atk-ks.org/wpcontent/uploads/2010/09/Raporti-i-punes-per-vitin-2014.pdf (01.03.2018)

[15] Annual work report 2015. Retrieved from http://www.atk-ks.org/wpcontent/uploads/2016/04/Raporti-i-punes-Janar-Dhjetor-2015-VF.pdf (01.03.2018)

[16] Annual work report 2016. Retrieved from http://www.atk-ks.org/wpcontent/uploads/2017/04/Raport-Vjetor-2016-per-publikim-0704-Neni-8Ligji-03L-222.pdf (01.03.2018)

[17] Annual report of Tax Administration of Kosovo. Reporting period: January - December 2016. Pristina, march 2017. Retrieved from http://www.atkks.org/wp-content/uploads/2017/04/Raport-Vjetor-2016-per-publikim0704-Neni-8-Ligji-03L-222.pdf (04.03.2018)

\section{AUTHORS}

First Author - Gentiana Mjaku, Ph.D. c, Department of Marketing, Faculty of Economics, University of Tetova 